\title{
Protective effects of honokiol against oxidative stress-induced apoptotic signaling in mouse podocytes treated with $\mathrm{H}_{2} \mathrm{O}_{2}$
}

\author{
FANG WU $^{1 *}$, HANGPING YAO $^{2 *}$, FENPING ZHENG $^{1}$, SHENGJIE TANG $^{1}$, \\ XIHUA LIN ${ }^{1}$, LIN LI ${ }^{1}$, JIAQIANG ZHOU ${ }^{1}$ and HONG LI ${ }^{1}$ \\ ${ }^{1}$ Department of Endocrinology, The Affiliated Sir Run Run Shaw Hospital, College of Medicine, Zhejiang University, \\ Hangzhou, Zhejiang 310016; ${ }^{2}$ State Key Laboratory for Diagnosis and Treatment of Infectious Diseases, \\ Institute of Infectious Diseases, The First Affiliated Hospital, College of Medicine, Zhejiang University, \\ Hangzhou, Zhejiang 310003, P.R. China
}

Received December 14, 2017; Accepted April 13, 2018

DOI: $10.3892 /$ etm.2018.6313

\begin{abstract}
Honokiol (HNK), an important bioactive compound purified from Magnolia officinalis Cortex, has been demonstrated to have manifold beneficial anti-oxidative, anti-inflammatory, anti-bacterial and antitumor pharmacological effects. In the present study, the association of HNK in the signaling mechanism associated with hydrogen peroxide $\left(\mathrm{H}_{2} \mathrm{O}_{2}\right)$-induced apoptosis of cultured mouse podocytes was investigated. HNK did not cause significant changes in podocyte viability when its concentration remained below $20 \mu \mathrm{M}$. MTS assay and flow cytometry confirmed that $\mathrm{H}_{2} \mathrm{O}_{2}$ significantly enhanced the rates of apoptosis while produce significant reduction in viability of podocytes. Following $24 \mathrm{~h}$ of pre-treatment with different concentrations of HNK, the viability of adherent podocytes increased and apoptosis significantly decreased in a dose-dependent manner below $20 \mu \mathrm{M}$. Reverse transcription-polymerase chain reaction and western blot results indicated that HNK significantly decreased the expression of mRNA and cleaved protein of caspase- 3 and caspase- 9 in podocytes pre-treated with $\mathrm{H}_{2} \mathrm{O}_{2}$. Furthermore, phosphorylation of the signaling molecules protein kinase B (Akt) and extracellular signal-regulated kinase (Erk) 1/2 appeared to increase following HNK treatment. In conclusion, HNK largely eliminated the role of promoting podocyte apoptosis in an oxidative stress environment, which was a protective factor on podocytes cultured with $\mathrm{H}_{2} \mathrm{O}_{2}$. The anti-oxidative stress mechanisms of HNK are partly due to
\end{abstract}

Correspondence to: Professor Hong Li, Department of Endocrinology, The Affiliated Sir Run Run Shaw Hospital, College of Medicine, Zhejiang University, 3 East Qingchun Road, Hangzhou, Zhejiang 310016, P.R. China

E-mail: srrshnfm@zju.edu.cn

${ }^{*}$ Contributed equally

Key words: honokiol, apoptosis, oxidative stress, podocyte suppressing the expression of caspase- 3 and caspase- 9 and upregulating phosphorylated-Akt and -Erk 1/2.

\section{Introduction}

Podocytes, also known as visceral glomerular epithelial cells, serve a critical role in maintaining the normal structure and function of the glomerular filtration barrier (1). A wide variety of glomerular diseases can lead to many abnormal structural deformations of podocytes, including podocyte foot process fusion and detachment from the glomerular basement membrane (GBM), GBM thickening and ultimately a reduction in podocytes (2). Manifold stimuli can lead to podocyte abnormality and apoptosis, including immune-mediated and oxidative stress, hemodynamic changes, hyperglycemia and hyperlipidemia (3). To date, it has been established that glycation end-products and reactive oxygen species (ROS) induced by hyperglycemia can result in ultrastructural alterations of the glomerular filtration barrier in diabetic kidney diseases (2). Tight control of blood glucose can delay the development of diabetic kidney disease (DKD), but this alone is not capable of preventing progression of diabetic nephropathy to end-stage renal damage (ESRD).

Oxidative stress is a particularly important cause of kidney injury and podocyte apoptosis, activating a series of phosphorylated kinases. These, in turn, induce expression of downstream transcription factors and contribute to increased apoptosis and detachment of podocytes that line the GBM (4). As highly specialized and terminally differentiated cells, podocytes lack regenerative capabilities $(4,5)$. ROS include free radicals, such as superoxide, as well as non-radical species (i.e., $\left.\mathrm{H}_{2} \mathrm{O}_{2}\right)$. A certain concentration $(200 \mu \mathrm{mol} / \mathrm{l})$ of $\mathrm{H}_{2} \mathrm{O}_{2}$ results in cell apoptosis (6). It is well established that signaling pathways associated with podocyte apoptosis mainly include the caspase, cyclin kinase and other such pathways. Caspase-9 is the initiator caspase in the intrinsic or mitochrondrial caspase pathway that functions to activate downstream caspase-3 in response to apoptotic signals (7).

Honokiol (HNK) is a natural bi-phenolic compound isolated from the Magnoliae officinalis Cortex, which is commonly used in Traditional Chinese Medicine. Magnolia 
extracts have been confirmed to exhibit anti-oxidative, anti-microbial, anti-inflammatory, and antitumor pharmacological effects (8). It has also been reported that Magnolia extracts may protect contrast-induced nephropathy in rats through antioxidation and antiapoptosis in the kidney (9). Previous studies revealed that HNK protects against renal or myocardial ischemia/reperfusion injury via the suppression of oxidative stress, inducible nitric oxide synthase and inflammation in rats (10-12). Therefore, the aim of the present study was to explore the protective effects exerted by $\mathrm{HNK}$ on cultured mouse podocytes and its effect on apoptosis induced by $\mathrm{H}_{2} \mathrm{O}_{2}$. The potential associated molecular mechanisms/signaling pathways were also investigated.

\section{Materials and methods}

Reagents. HNK (purity, 98.7\%) was obtained from the National Institute for the Control of Pharmaceutical and Biological Products of China (Beijing, China). $\mathrm{H}_{2} \mathrm{O}_{2}$ was obtained from Sigma-Aldrich; Merck KGaA (Darmstadt, Germany). A CellTiter $96^{\circledR}$ AQueous Non-Radioactive Cell Proliferation Assay (MTS) was procured from Promega Corporation (Madison, WI, USA). Annexin V-FITC Apoptosis Detection kit was purchased from BD Biosciences (Franklin Lakes, NJ, USA). Polyclonal antibodies against cleaved caspase-3 (cat. no. 9664), cleaved-caspase-9 (cat. no. 7237), protein kinase B (Akt; cat. no. 4685), extracellular signal-regulated kinase (Erk) 1/2 (cat. no. 4695), phosphorylated (p-)Akt (cat. no. 4060), p-Erk 1/2 (cat. no. 4376) and $\beta$-actin (cat. no. 4970S) were all obtained from Cell Signaling Technology, Inc. (Danvers, MA, USA).

Cell culture. Conditionally immortalized mouse podocytes were purchased from Type Culture Collection of the Chinese Academy of Sciences (Shanghai, China). Cells were cultured in RPMI 1640 (Gibco; Thermo Fisher Scientific, Inc., Waltham, MA, USA) supplemented with $10 \%$ heat-inactivated fetal bovine serum (Gibco; Thermo Fisher Scientific, Inc.), $25 \mathrm{mM}$ glucose and antibiotics (penicillin and streptomycin) at $37^{\circ} \mathrm{C}$ in humidified air with $5 \% \mathrm{CO}_{2}$. The morphology of podocytes treated with $\mathrm{H}_{2} \mathrm{O}_{2}$ in the absence or presence of different concentrations $(1.25,5$ and $20 \mu \mathrm{M})$ of HNK was observed using images obtained from an inverted microscope (Olympus IX81; Olympus Corporation, Tokyo, Japan; magnification, $\mathrm{x} 100)$.

Viability evaluation. Cultured mouse podocytes ( $1 \times 10^{4}$ cells/well in 96-well plate) were pre-treated with HNK $(0,1.25,5$ and $20 \mu \mathrm{M})$ for $2 \mathrm{~h}$ at $37^{\circ} \mathrm{C}$ and further incubated in the presence of $100 \mu \mathrm{M} \mathrm{H}_{2} \mathrm{O}_{2}$ for $24 \mathrm{~h}$ at $37^{\circ} \mathrm{C}$ The groups (excluding group $1 ; 0 \mu \mathrm{M} \mathrm{H}_{2} \mathrm{O}_{2}+0 \mu \mathrm{M} \mathrm{HNK}$ ) were pretreated with $\mathrm{HNK} 2 \mathrm{~h}$ prior to the addition of $\mathrm{H}_{2} \mathrm{O}_{2}$ and then sustained with the same concentration of HNK for $24 \mathrm{~h}$ to assess the effects of HNK. Additionally, group 6 was treated with $20 \mu \mathrm{M}$ $\mathrm{HNK}$ without $\mathrm{H}_{2} \mathrm{O}_{2}$ in order to assess if a high concentration of $\mathrm{HNK}$ affected the viability of cells. Cell viability was evaluated using an MTS assay. Following incubation in the appropriate medium, $20 \mu \mathrm{l}$ phenazine methosulfate (an electron coupling reagent) was added to each well for $1 \mathrm{~h}$ at $37^{\circ} \mathrm{C}$ in $5 \% \mathrm{CO}_{2}$ and absorbance was measured at $490 \mathrm{~nm}$.
Flow cytometry analysis. At 24 h following $\mathrm{H}_{2} \mathrm{O}_{2}$ treatment, the apoptosis of cells treated with or without HNK were monitored. Annexin V binding and propidium iodide (PI) staining were determined by flow cytometry. Cells were washed with PBS twice, and double stained at $37^{\circ} \mathrm{C}$ with the fluorescein isothiocyanate (FITC)-conjugated Annexin V protein and PI for $20 \mathrm{~min}$. Flow cytometry was performed using a $488 \mathrm{~nm}$ laser coupled to a flow cytometer (FACSCalibur; BD Biosciences, San Jose, CA, USA) to detect intact cells $\left(\mathrm{FITC}^{-} / \mathrm{PI}^{-}\right)$, apoptotic cells $\left(\mathrm{FITC}^{+} / \mathrm{PI}^{-}\right)$and necrotic cells $\left(\mathrm{FITC}^{-} / \mathrm{PI}^{+}\right)$. The data was analyzed using BD FACSDiva 6.0 software (BD Biosciences).

Western blotting. Cultured mouse podocytes $\left(5 \times 10^{6} / 10-\mathrm{cm}\right.$ dish) were pre-treated with different concentrations $(0,1.25,5$ and $20 \mu \mathrm{M}$ ) of $\mathrm{HNK}$ for $2 \mathrm{~h}$ and followed by $100 \mu \mathrm{M} \mathrm{H}_{2} \mathrm{O}_{2}$ for $24 \mathrm{~h}$ at $37^{\circ} \mathrm{C}$. Cells were collected and lysed with lysis buffer (20 mM Tris- $\mathrm{HCl}$ (pH 7.5), $150 \mathrm{mM} \mathrm{NaCl}, 1 \mathrm{mM}$ EDTA, $1 \%$ Triton, 1\% NP-40, $2.5 \mathrm{mM}$ sodium pyrophosphate, $1 \mathrm{mM}$ $\beta$-glycerophosphate, $1 \mathrm{mM}$ leupeptin, $1 \mathrm{mM}$ phenylmethylsulfonyl fluoride) for $30 \mathrm{~min}$ at $4^{\circ} \mathrm{C}$. Extracted protein in each cell lysate was determined using a bicinchoninic acid protein assay kit (Pierce; Thermo Fisher Scientific, Inc.). Proteins were transferred to a polyvinylidene difluoride membrane and blocked with $5 \%$ non-fat dry milk in PBS with $0.02 \% \mathrm{v} / \mathrm{v}$ Tween-20 (PBS-Tween) for $2 \mathrm{~h}$ at room temperature. The membrane was incubated for $16 \mathrm{~h}$ at $4^{\circ} \mathrm{C}$ with the aforementioned primary antibodies at a dilution of 1:1,000. However, anti- $\beta$-actin was used at a dilution of 1:2,000. The membrane was washed and subsequently incubated for $1 \mathrm{~h}$ at room temperature with a peroxidase-labeled Rabbit anti-Goat IgG antibody (cat. no. SA00001-4; 1:5,000; ProteinTech Group, Inc., Chicago, IL, USA). Following further washing, the membrane was analyzed using an enhanced chemiluminescence kit (Pierce; Thermo Fisher Scientific, Inc.).

Extraction of total RNA and reverse transcription-polymerase chain reaction $(R T-P C R)$. Total RNA was extracted from cell lines using RNAiso Plus (Takara Bio, Inc., Otsu, Japan) according to the manufacturer's instructions. Samples were stored at $-80^{\circ} \mathrm{C}$ prior to further use. First chain cDNA synthesis was performed using the PrimeScript ${ }^{\text {TM }}$ RT Reagent kit (Takara Bio, Inc.) according to the manufacturer's instructions and PCR was subsequently performed using the SYBR Premix Ex Taq kit (Takara Bio, Inc.). Primer sequences used were as follows: Caspase-3 forward, 5'-CGTGGTTCATCC AGTCCCTTT-3' and reverse, 5'-ATTCCGTTGCCACCT TCCT-3'; caspase-9 forward, 5'-ATCGACCCTCCGCCA GA-3' and reverse, 5'-CAAAGGAAGCAGAACCCAT-3'; and $\beta$-actin forward, 5'-CTCTTCCAGCCTTCCTTCCT-3' and reverse, 5'-CACCTTCACCGTTCCAGTTT-3'. The thermocycling conditions were as follows: $95^{\circ} \mathrm{C}$ for $5 \mathrm{~min}$, followed by 40 cycles at $95^{\circ} \mathrm{C}$ for $15 \mathrm{sec}, 60^{\circ} \mathrm{C}$ for $20 \mathrm{sec}$ and $72^{\circ} \mathrm{C}$ for $20 \mathrm{sec}$, and a final extension at $72^{\circ} \mathrm{C}$ for $10 \mathrm{~min}$.

Statistical analysis. All experiments were performed in triplicate and data are presented as means \pm standard deviation. Statistical significance was determined using one-way analysis of variance followed by a Fisher's least significant difference test. Statistical analyses were performed 


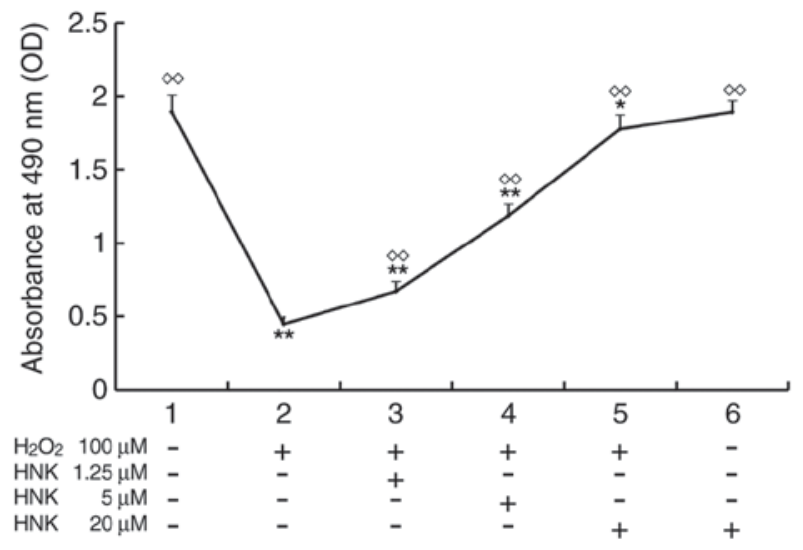

Figure 1. Effect of HNK on the viability of podocytes treated with $\mathrm{H}_{2} \mathrm{O}_{2}$. Podocytes $\left(1 \times 10^{4}\right.$ cells/well) were incubated with HNK at different concentrations and $100 \mu \mathrm{M} \mathrm{H}_{2} \mathrm{O}_{2}$ for $24 \mathrm{~h}$. Cell viability was determined via MTS assay. Data are represented as the mean \pm the standard error of the mean $(\mathrm{n}=3) .{ }^{*} \mathrm{P}<0.05,{ }^{* *} \mathrm{P}<0.01$ vs. normal control (group 1 ); ${ }^{\circ} \mathrm{P}<0.01$ vs. $\mathrm{H}_{2} \mathrm{O}_{2}$ treated alone (group 2). HNK, honokiol; OD, optical density.

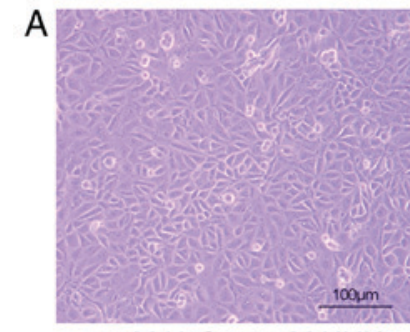

$0 \mu \mathrm{M} \mathrm{H}_{2} \mathrm{O}_{2}+0 \mu \mathrm{M} \mathrm{HNK}$

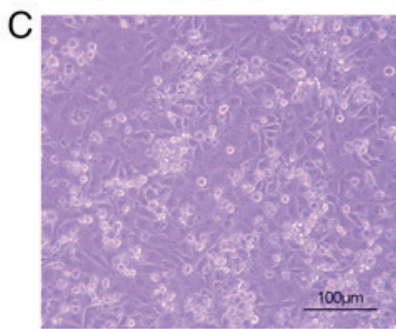

$100 \mu \mathrm{M} \mathrm{H}_{2} \mathrm{O}_{2}+0 \mu \mathrm{M} \mathrm{HNK}$

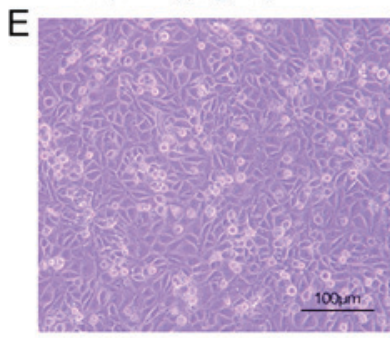

$100 \mu \mathrm{M} \mathrm{H}_{2} \mathrm{O}_{2}+5 \mu \mathrm{M} \mathrm{HNK}$

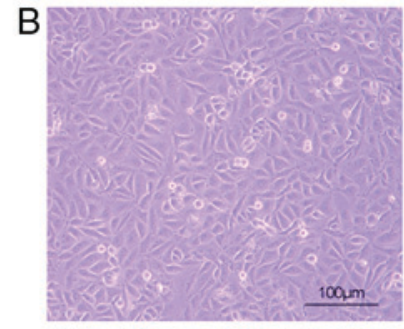

$0 \mu \mathrm{M} \mathrm{H}_{2} \mathrm{O}_{2}+20 \mu \mathrm{M} \mathrm{HNK}$
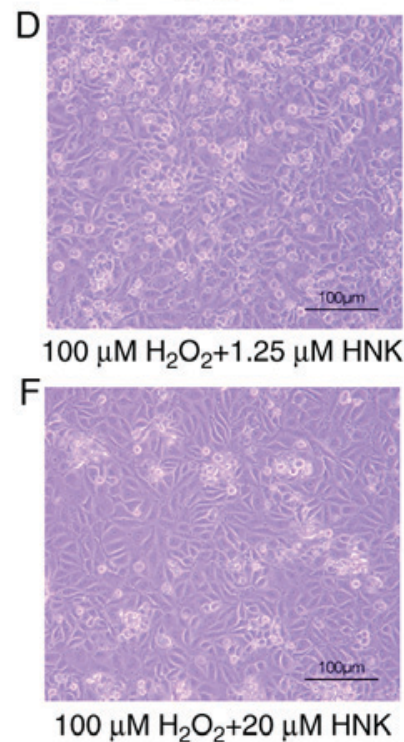

Figure 2. Cell morphologic changes of podocytes treated with HNK and $100 \mu \mathrm{M} \mathrm{H}_{2} \mathrm{O}_{2}$ as viewed under light microscopy. Following treatment with $\mathrm{HNK}$ and $100 \mu \mathrm{M} \mathrm{H}_{2} \mathrm{O}_{2}$ for $24 \mathrm{~h}$, cells were photographed under light microscopy. Cells were divided into the following treatment groups: (A) $0 \mu \mathrm{M} \mathrm{H}_{2} \mathrm{O}_{2}$ $+0 \mu \mathrm{M}$ HNK (normal control), (B) $0 \mu \mathrm{M} \mathrm{H}_{2} \mathrm{O}_{2}+20 \mu \mathrm{M} \mathrm{HNK}$, (C) $100 \mu \mathrm{M}$ $\mathrm{H}_{2} \mathrm{O}_{2}+0 \mu \mathrm{M} \mathrm{HNK}$, (D) $100 \mu \mathrm{M} \mathrm{H}_{2} \mathrm{O}_{2}+1.25 \mu \mathrm{M} \mathrm{HNK}$, (E) $100 \mu \mathrm{M}$ $\mathrm{H}_{2} \mathrm{O}_{2}+5 \mu \mathrm{M}$ HNK and (F) $100 \mu \mathrm{M} \mathrm{H}_{2} \mathrm{O}_{2}+20 \mu \mathrm{M}$ HNK. The magnification scale was $100 \mu \mathrm{m}$ when taking photos.

using SPSS 16.0 software (SPSS, Inc., Chicago, IL, USA). $\mathrm{P}<0.05$ was considered to indicate a statistically significant difference.

\section{Results}

Effects of HNK on viability of mouse podocytes treated with $\mathrm{H}_{2} \mathrm{O}_{2}$. Cultured mouse podocytes were pre-treated with HNK $(0,1.25,5,20 \mu \mathrm{M})$ for $2 \mathrm{~h}$ and further incubated with $100 \mu \mathrm{M}$ $\mathrm{H}_{2} \mathrm{O}_{2}$ (excluding groups 1 and 6) for $24 \mathrm{~h}$. Cell viability was evaluated via MTS assay. Results revealed that mouse podocytes retained almost the same levels of viability following exposure to incubation conditions with HNK concentrations of $20 \mu \mathrm{M}$ (group 6) compared with the normal control (group 1), suggesting that HNK did not affect podocyte viability at certain concentrations. However, as $100 \mu \mathrm{M} \mathrm{H}_{2} \mathrm{O}_{2}$ significantly reduced cell viability (group 2), the OD value was only $\sim 25 \%$ of that in group $1(\mathrm{P}<0.01)$. Following pre-treatment with different concentrations of HNK, the rate of cell viability increased in a concentration-dependent manner. OD values of groups treated with HNK at low, medium and high concentrations were $1.39(\mathrm{P}<0.01), 2.5(\mathrm{P}<0.01)$ and 3.73 times $(\mathrm{P}<0.01)$ higher, respectively, when compared with the group treated with $\mathrm{H}_{2} \mathrm{O}_{2}$ alone (Fig. 1).

Effect of HNK on morphologic changes in podocytes treated with $\mathrm{H}_{2} \mathrm{O}_{2}$. Following pre-treatment with different concentrations of $\mathrm{HNK}$ for $2 \mathrm{~h}$ and $100 \mu \mathrm{M} \mathrm{H}_{2} \mathrm{O}_{2}$ for $24 \mathrm{~h}$, podocytes were observed and photographed using an inverted microscope. Microscopic observation revealed that $100 \mu \mathrm{M} \mathrm{H}_{2} \mathrm{O}_{2}$ markedly affected cell physiology. Numerous dead podocytes were noted floating in the supernatant, whereas weakly adhered cells were observed as opaque, black-spotted masses. Podocytes treated with HNK alone exhibit a morphology similar to the control group with only a few floating cells in the supernatant. Following treatment with $\mathrm{H}_{2} \mathrm{O}_{2}$ and different concentrations of HNK for $24 \mathrm{~h}$, the morphology of podocytes improved in a dose-dependent manner and cells gradually became more transparent (Fig. 2).

Effects of HNK on podocyte apoptosis induced by $\mathrm{H}_{2} \mathrm{O}_{2}$. Results of flow cytometry revealed that the ratio of apoptotic podocytes did not markedly differ between control and $20 \mu \mathrm{M}$ HNK treatment groups following $24 \mathrm{~h}$. Although $\mathrm{H}_{2} \mathrm{O}_{2}$ typically results in an increased apoptotic ratio, treatment with different concentrations of HNK resulted in markedly decreases in the ratio of apoptosis in podocytes. Compared with the $\mathrm{H}_{2} \mathrm{O}_{2}$-treated group, the ratio of apoptosis in groups treated with low, medium and high concentrations of HNK were decreased gradually. However, the apoptosis ratio of groups treated with high concentrations of HNK remained slightly higher than that of the control group (Fig. 3).

Effects of HNK on the expression of caspase-3 and caspase-9. Caspases (proteases) serve an important role in extrinsic and intrinsic apoptotic pathways. The RT-PCR results indicated that mRNA expression of caspase- 3 and caspase- 9 both increased in podocytes treated with $\mathrm{H}_{2} \mathrm{O}_{2}$ compared with control cells. Additionally, although mRNA levels of caspase 9 were marginally higher in cells treated with $100 \mu \mathrm{M} \mathrm{H}_{2} \mathrm{O}_{2}+1.25 \mu \mathrm{M}$ HNK than in those treated with $100 \mu \mathrm{M} \mathrm{H}_{2} \mathrm{O}_{2}$ alone, HNK gradually downregulated expression of cleaved caspase- 3 and caspase-9 mRNA in a concentration from 5 to $20 \mu \mathrm{M}$ (Fig. 4). Furthermore, western blotting analysis of cleaved caspase-3 

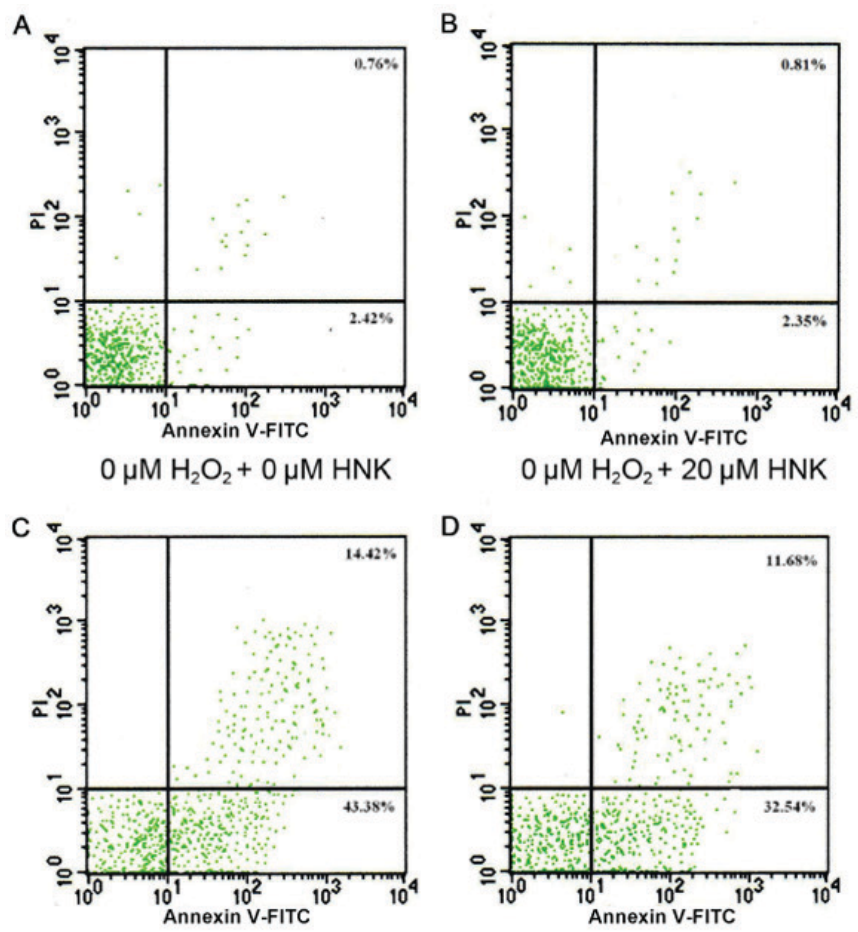

$100 \mu \mathrm{M} \mathrm{H}_{2} \mathrm{O}_{2}+0 \mu \mathrm{M} \mathrm{HNK}$
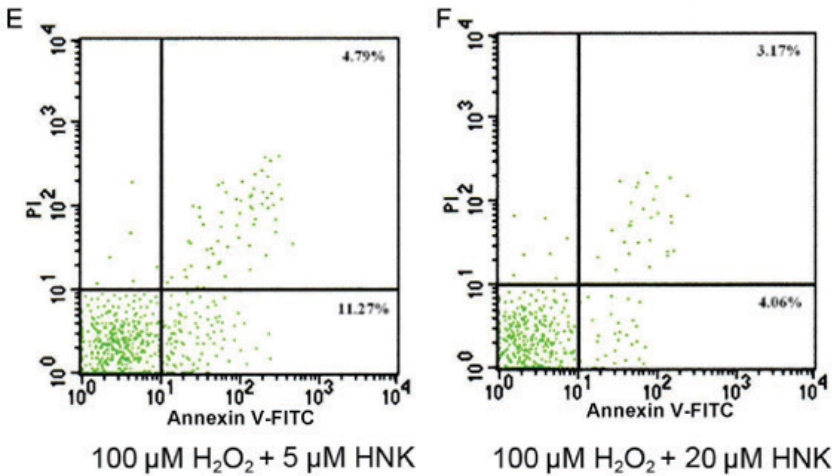

Figure 3. The protective effect of HNK on apoptosis in podocytes treated with $\mathrm{H}_{2} \mathrm{O}_{2}$. Podocytes were cultured under different concentrations $(0-20 \mu \mathrm{M})$ of $\mathrm{HNK}$ and $\mathrm{H}_{2} \mathrm{O}_{2}$. Following $24 \mathrm{~h}$, podocytes were collected and cell apoptosis was detected via Annexin V/PI staining methods with flow cytometry. Experiments were performed in triplicate. Cells were divided into the following treatment groups: (A) $0 \mu \mathrm{M} \mathrm{H}_{2} \mathrm{O}_{2}+0 \mu \mathrm{M} \mathrm{HNK}$ (normal control), (B) $0 \mu \mathrm{M} \mathrm{H}_{2} \mathrm{O}_{2}+20 \mu \mathrm{M} \mathrm{HNK}$, (C) $100 \mu \mathrm{M} \mathrm{H}_{2} \mathrm{O}_{2}+0 \mu \mathrm{M} \mathrm{HNK}$, (D) $100 \mu \mathrm{M}$ $\mathrm{H}_{2} \mathrm{O}_{2}+1.25 \mu \mathrm{M} \mathrm{HNK}$, (E) $100 \mu \mathrm{M} \mathrm{H}_{2} \mathrm{O}_{2}+5 \mu \mathrm{M} \mathrm{HNK}$ and (F) $100 \mu \mathrm{M} \mathrm{H}_{2} \mathrm{O}_{2}$ $+20 \mu \mathrm{M}$ HNK. HNK, honokiol; PI, propidium iodide; FITC, fluorescein isothiocyanate.

and caspase-9 protein levels produced similar findings as those of their mRNA levels, although the protein level of cleaved caspase-3 was margnally higher in cells treated with $100 \mu \mathrm{M}$ $\mathrm{H}_{2} \mathrm{O}_{2}+1.25 \mu \mathrm{M}$ HNK than in those treated with $100 \mu \mathrm{M} \mathrm{H}_{2} \mathrm{O}_{2}$ alone (Fig. 5). These results suggested an obvious inhibition of cleaved caspase- $3,-9$ protein and caspase-3, -9 mRNA expression by HNK.

Mechanisms associated with $\mathrm{HNK}$-inhibition of $\mathrm{H}_{2} \mathrm{O}_{2}$-induced oxidative stress in mouse podocytes. Recent findings have demonstrated that Akt and Erk signaling pathways is associated with the regulation of apoptosis in various of cell types, tissues and organs in many diseases (13-15). In the present study, protein levels of total Akt and Erk 1/2 exhibited no

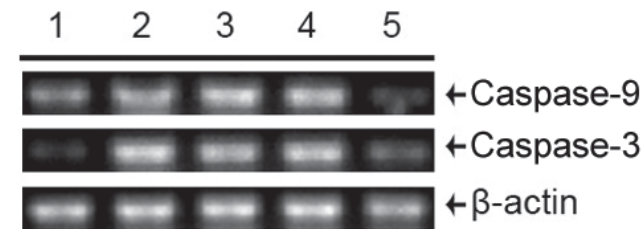

Figure 4. Detection of caspase-3 and -9 in podocytes treated with HNK and $\mathrm{H}_{2} \mathrm{O}_{2}$. Podocytes were treated with different concentrations of $\mathrm{HNK}$ and $100 \mu \mathrm{M} \mathrm{H}_{2} \mathrm{O}_{2}$ for $24 \mathrm{~h}$. Expression of caspase-3 and -9 mRNA was evaluated by reverse transcription-polymerase chain reaction. Cells were divided into the following treatment groups: $1,0 \mu \mathrm{M} \mathrm{H}_{2} \mathrm{O}_{2}+0 \mu \mathrm{M} \mathrm{HNK}$ (normal control); $2,100 \mu \mathrm{M} \mathrm{H}_{2} \mathrm{O}_{2}+0 \mu \mathrm{M} \mathrm{HNK} ; 3,100 \mu \mathrm{M} \mathrm{H}_{2} \mathrm{O}_{2}+1.25 \mu \mathrm{M} \mathrm{HNK} ; 4,100 \mu \mathrm{M}$ $\mathrm{H}_{2} \mathrm{O}_{2}+5 \mu \mathrm{M} \mathrm{HNK}$; and 5, $100 \mu \mathrm{M} \mathrm{H}_{2} \mathrm{O}_{2}+20 \mu \mathrm{M}$ HNK. HNK, honokiol.

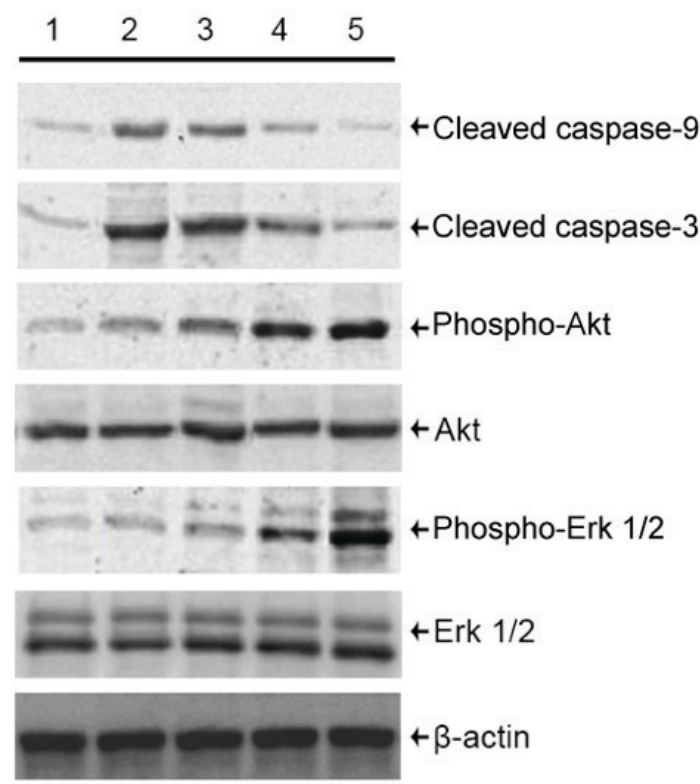

Figure 5. Detection of cleaved caspase-3 and -9 protein, p-Akt and p-Erk $1 / 2$ protein levels in podocytes treated with $\mathrm{HNK}$ and $\mathrm{H}_{2} \mathrm{O}_{2}$. Levels of cleaved caspase-3 and -9 protein, Akt, Erk 1/2, p-Akt and p-Erk 1/2 protein were detected by western blotting. Cells were divided into the following treatment groups: 1, $0 \mu \mathrm{M} \mathrm{H}_{2} \mathrm{O}_{2}+0 \mu \mathrm{M} \mathrm{HNK}$ (normal control); 2, $100 \mu \mathrm{M}$ $\mathrm{H}_{2} \mathrm{O}_{2}+0 \mu \mathrm{M} \mathrm{HNK} ; 3,100 \mu \mathrm{M} \mathrm{H}_{2} \mathrm{O}_{2}+1.25 \mu \mathrm{M} \mathrm{HNK} ; 4,100 \mu \mathrm{M} \mathrm{H}_{2} \mathrm{O}_{2}$ $+5 \mu \mathrm{M} \mathrm{HNK}$; and 5, $100 \mu \mathrm{M} \mathrm{H}_{2} \mathrm{O}_{2}+20 \mu \mathrm{M}$ HNK. HNK, honokiol. p, phosphorylated; Akt, protein kinase B; Erk, extracellular signal-regulated kinase; HNK, honokiol.

marked changes, whereas levels of p-Akt and p-Erk 1/2 appeared to increase following HNK treatment, peaking at the highest concentration of HNK $(20 \mu \mathrm{M})$. However, levels of p-Akt and p-Erk 1/2 did not exhibit any marked declines following $\mathrm{H}_{2} \mathrm{O}_{2}$ treatment alone. To some extent, p-Akt and p-Erk $1 / 2$ levels increased in cells treated with $\mathrm{H}_{2} \mathrm{O}_{2}$ compared with the control group, suggesting an inconsistent tendency associated with the expression of caspase in cells pre-treated with HNK (Fig. 5).

\section{Discussion}

An increased amount of urinary protein, termed albuminuria (typically $67 \mathrm{kDa}$ ), is among the earliest signs of DKD and strongly correlates with progression towards ESRD (2). The glomerular filtration barrier consists of three layers: 
Capillary endothelium, GBM and the glomerular epithelial cell (or podocyte) layer. Numerous studies (16-18) concerning DKD emphasized damage to mesangial cells and the glomerular basement membrane. Glomerular hypertrophy, mesangial matrix expansion and GBM thickening are classic signs of diabetic glomerular diseases (19). Previous evidence (20-22) have demonstrated that the onset of proteinuria is closely associated with pathological changes in podocytes, such as hypertrophy, detachment, apoptosis and epithelial-to-mesenchymal transition.

ROS promotes renal injury, exacerbating the progression of kidney disease (2). Previous studies $(23,24)$ have demonstrated that ameliorating oxidative stress through treatment with antioxidants may be an effective strategy for reducing diabetic complications. Several clinical $(25,26)$ trials have confirmed the effects of certain antioxidants on the prevention of diabetic complications. Under normal physiological conditions, the levels of cellular ROS remain stable in a dynamic equilibrium. The destruction of this balance promotes ROS accumulation, which causes molecular, cellular and clinical abnormalities (6). In the present study, data from the MTS assay revealed that $100 \mu \mathrm{M} \mathrm{H}_{2} \mathrm{O}_{2}$ significantly reduced cell viability, with the OD value being $25 \%$ of the normal control group with identical flow cytometry outcomes. In addition, observation under inverted microscopy indicated that $100 \mu \mathrm{M}$ $\mathrm{H}_{2} \mathrm{O}_{2}$ significantly affected cellular physiology.

HNK serves an anti-oxidative role by inhibiting NADPH oxidase, myeloperoxidase and cyclooxygenase while increasing glutathione peroxidase activity in neutrophils to promote metabolism of $\mathrm{H}_{2} \mathrm{O}_{2}$ (27). The present study demonstrated that $\mathrm{H}_{2} \mathrm{O}_{2}$ reduces the ratio of viable podocytes as well as increases the ratio of cell apoptosis. Additionally, cultured mouse podocytes were pre-treated with $\operatorname{HNK}(0,1.25,5$ and $20 \mu \mathrm{M}$ ) for $2 \mathrm{~h}$ and further incubated in $100 \mu \mathrm{M} \mathrm{H}_{2} \mathrm{O}_{2}$ for $24 \mathrm{~h}$. The effect of HNK on peroxide-induced podocyte apoptosis was subsequently investigated. Podocytes were also treated with high concentrations $(20 \mu \mathrm{M})$ of HNK alone to observe the influence of HNK on cellular viability and apoptosis as well. Following $24 \mathrm{~h}$ treatment with different concentrations of $\mathrm{HNK}$ and $100 \mu \mathrm{M} \mathrm{H}_{2} \mathrm{O}_{2}$, the morphology of adherent podocytes improved in a dose-dependent manner compared with $\mathrm{H}_{2} \mathrm{O}_{2}$ treatment alone. In addition, $\mathrm{HNK}$ treatment alone did not markedly alter podocyte physiology in comparison with the control group. These results demonstrated that HNK, within certain safe ranges of concentration, can protect podocytes from damage induced by oxidative stress. MTS assay and flow cytometry further confirmed that HNK treatment lead to significantly lower apoptotic ratios and greater viability rates in podocytes. Nonetheless, the ratio of apoptosis in cells treated with HNK at high concentrations remained slightly higher as compared with the control group.

Casepase- 9 is generally considered to be an initial mediator of apoptosis induced by $\mathrm{H}_{2} \mathrm{O}_{2}$ (28). The eventual release of cytochrome $\mathrm{C}$ promotes activation of caspase-3 (which can also be activated to strengthen caspase-3), thus resulting in activation of caspase-associated DNase. Activated DNase degrades DNA to mere fragments. This is one important marker of cellular apoptosis (28). In the present study, RT-PCR and western blotting results confirmed that the expression of both mRNA and protein of cleaved caspase- 3 and -9 markedly increased in podocytes treated with $\mathrm{H}_{2} \mathrm{O}_{2}$. Pretreatment with HNK markedly downregulated expression of both protein and mRNA of caspase-3 and -9 in a concentration-dependent manner.

Previous studies also reported the anti-apoptotic effects of hepatocyte growth factor (HGF) on podocytes in vitro. HGF stimulation resulted in the phosphorylation of Akt and Erk, and induction of an X-linked inhibitor of apoptosis protein (XIAP) in podocytes (29). Furthermore, phosphorylation of Akt and Erk 1/2 was attenuated, whereas the expression of cleaved caspase- 3 and the number of TUNEL positive cells was enhanced in vascular endothelial cells exposed to $\mathrm{H}_{2} \mathrm{O}_{2}$ (30). In another study, cultured mouse neural progenitor cells were treated with $\mathrm{H}_{2} \mathrm{O}_{2}$, apoptotic signaling pathways were activated and the phosphorylation of Akt and Erk decreased. Astaxanthin pretreatment, however, significantly inhibited $\mathrm{H}_{2} \mathrm{O}_{2}$-mediated caspase activation (31). The activation of phosphorylation of Erk 1/2, which blocked the release of cytochrome $\mathrm{C}$ from mitochondria, resulted in inhibition of caspase- 9 and -3 activation. The ratio of apoptosis also decreased (31). The phosphoinositide 3-kinase (PI3K)/Akt/glycogen synthase kinase (GSK)-3 signal transduction pathway is a vital modality of intracellular membrane receptor signal transduction and serves an important role in the regulation of apoptosis in a variety of organs (32). Akt is a serine/threonine protein kinase characterized by multiple sites of phosphorylation. PI3K inhibits the downstream apoptosis-related protein GSK-3 $\beta$ by enhancing the activation of Akt, thus having an anti-apoptotic effect. GSK-3 serves a critical role in regulation of apoptosis, which can inhibit transcription factors, such as heat shock factor-1 (a cyclic adenosine monophosphate binding protein) and activate members of the caspase family, leading to apoptosis $(32,33)$.

The present data indicated that as HNK concentration increased, total Akt and Erk 1/2 protein levels did not markedly change. However, levels of p-Akt and Erk $1 / 2$ gradually increased, peaking at $20 \mu \mathrm{M}$ HNK in a concentration-dependent manner. As the expression of cleaved caspase- 3 and -9 gradually decreased, levels of p-Akt and -Erk 1/2 increased with HNK treatment. Notably, in the present study, levels of p-Akt and -Erk 1/2 in the group treated with $\mathrm{H}_{2} \mathrm{O}_{2}$ alone did not significantly decrease as compared with the normal control group. This phenomenon seemed inconsistent with the tendency of the expression of caspase in HNK-treated cells and contradicted the results of MTS and flow cytometry. It was speculated that the potency of $\mathrm{H}_{2} \mathrm{O}_{2}$ inevitably weakens as time passes, and cells exhibit a certain degree of self-repair capacity. Levels of p-Akt and Erk $1 / 2$ therefore increased slightly under $\mathrm{H}_{2} \mathrm{O}_{2}$ treatment alone following 24-h incubation. Nevertheless, the effects observed in the present study are not necessarily indicative of a cause-and-effect relationship. Furthermore, it is necessary to interfere with Akt and Erk at the genetic level to confirm the targets of $\mathrm{HNK}$ in $\mathrm{H}_{2} \mathrm{O}_{2}$-treated podocytes.

In conclusion, the present study confirmed that HNK serves a vital role in protecting against apoptosis in podocytes treated with $\mathrm{H}_{2} \mathrm{O}_{2}$ by means of inhibiting caspase- 3 and -9 activation as well as enhancing phosphorylation of Akt and Erk 1/2.HNK may have potential as a treatment for kidney diseases exacerbated by oxidative stress damage. 


\section{Acknowledgements}

Not applicable.

\section{Funding}

The present study was supported by the Zhejiang Provincial Natural Science Foundation of China (LY14H070002 and LQ16H070001), the Zhejiang Provincial Medical Science and Technology Program (Backbone Project of Platform Program; 2015RCA013) and the Zhejiang Provincial Administration of traditional Chinese Medicine Project (2015ZA058).

\section{Availability of data and materials}

The datasets used and/or analyzed during the current study are available from the corresponding author on reasonable request.

\section{Authors' contributions}

FW and HY conceived and designed the study, wrote the protocol, performed the experiments, analyzed the data, performed the literature search and approved the final manuscript. FZ, JZ and HL supervised the research and contributed to the flow cytometric analysis and cell viability evaluation. XL, LL and ST were involved in data acquisition and helped perform the cell biology experiments. FW wrote the first draft of the manuscript, HL helped revise the manuscript. All co-authors approved the final version of the manuscript. FW and HY had full access to all the data in this study and take responsibility for the integrity of the data.

\section{Ethics approval and consent to participate}

Not applicable.

\section{Consent for publication}

Not applicable.

\section{Competing interests}

The authors declare that they have no competing interests.

\section{References}

1. Thorner PS, Ho M, Eremina V, Sado Y and Quaggin S: Podocytes contribute to the formation of glomerular crescents. J Am Soc Nephrol 19: 495-502, 2008.

2. Gnudi L, Coward RJM and Long DA: Diabetic nephropathy: Perspective on novel molecular mechanisms. Trends Endocrino Metab 27: 820-830, 2016.

3. Marshall CB and Shankland SJ: Cell cycle and glomerular disease: A minireview. Nephron Exp Nephrol 102: e39-e48, 2006.

4. Xia H, Bao W and Shi S: Innate immune activity in glomerular podocytes. Front Immunol 8: 122, 2017.

5. Shibata S, Nagase M, Yoshida S, Kawachi H and Fujita T: Podocyte as the target for aldosterone: Roles of oxidative stress and Sgk1. Hypertension 49: 355-364, 2007.

6. Johansen JS, Harris AK, Rychly DJ and Ergul A: Oxidative stress and the use of antioxidants in diabetes: Linking basic science to clinical practice. Cardiovasc Diabetol 4: 5, 2005.
7. ZouH, Yang R,Hao J,Wang J,Sun C,Fesik SW,Wu JC, Tomaselli KJ and Armstrong RC: Regulation of the Apaf-1/caspase-9 apoptosome by caspase-3 and XIAP: J Biol Chem 278: 8091-8098, 2003.

8. Fried LE and Arbiser JL: Honokiol, a multifunctional antiangiogenic and antitumor agent. Antioxid Redox Signal 11: 1139-1148, 2009.

9. Wang F, Zhang G, Zhou Y, Gui D, Li J, Xing T and Wang N: Magnolin protects against contrast-induced nephropathy in rats via antioxidation and antiapoptosis: Oxid Med Cell Longev 2014: 203458, 2014.

10. Wang Y, Zhang ZZ, Wu Y, Zhan J, He XH and Wang YL: Honokiol protects rat hearts against myocardial ischemia reperfusion injury by reducing oxidative stress and inflammation. Exp Ther Med 5: 315-319, 2013.

11. Wu F, Zhang W, Li L, Zheng F, Shao X, Zhou J and Li H: Inhibitory effects of honokiol on lipopolysaccharide-induced cellular responses and signaling events in human renal mesangial cells. Eur J Pharmacol 654: 117-121, 2011.

12. Yu Y, Li M, Su N, Zhang Z, Zhao H, Yu H and Xu Y: Honokiol protects against renal ischemia/reperfusion injury via the suppression of oxidative stress, iNOS, inflammation and STAT3 in rats. Mol Med Rep 13: 1353-1360, 2016.

13. Zeng W, Tang J, Li H, Xu H, Lu H, Peng H, Lin C, Gao R, Lin S, Lin K, et al: Caveolin-1 deficiency protects pancreatic $\beta$ cells against palmitate-induced dysfunction and apoptosis. Cell Signal 47: 65-78, 2018.

14. Li L, Wang X, Sharvan R, Gao J and Qu S: Berberine could inhibit thyroid carcinoma cells by inducing mitochondrial apoptosis, G0/G1 cell cycle arrest and suppressing migration via PI3K-AKT and MAPK signaling pathways. Biomed Pharmacother 95: 1225-1231, 2017

15. Zhang B, Shen Q, Chen Y, Pan R, Kuang S, Liu G, Sun G and Sun X: myricitrin alleviates oxidative stress-induced inflammation and apoptosis and protects mice against diabetic cardiomyopathy. Sci Rep 7: 44239, 2017.

16. Sargin AK, Can B and Turan B: Comparative investigation of kidney mesangial cells from increased oxidative stress induced diabetic rats by using different microscopy techniques. Mol Cell Biochem 390: 41-49, 2014.

17. Thomson SE, McLennan SV, Kirwan PD, Heffernan SJ, Hennessy A, Yue DK and Twigg SM: Renal connective tissue growth factor correlates with glomerular basement membrane thickness and prospective albuminuria in a non-human primate model of diabetes: Possible predictive marker for incipient diabetic nephropathy. J Diabetes Complications 22: 284-294, 2008.

18. Wang A, Ziyadeh FN, Lee EY, Pyagay PE, Sung SH, Sheardown SA, Laping $\mathrm{NJ}$ and Chen S: Interference with TGF-beta signaling by Smad3-knockout in mice limits diabetic glomerulosclerosis without affecting albuminuria. Am J Physiol Renal Physiol 293: F1657-F1665, 2007.

19. Osterbt R and Gundersen HJ: Glomerular size and structure in diabetes mellitus. I. Early abnormalities. Diabetologia 11: 225-229, 1975.

20. Jefferson JA, Shankland SJ and Pichler RH: Proteinuria in diabetic kidney disease: A mechanistic viewpoint. Kidney Int 74: 22-36, 2008.

21. White KE, Bilous RW, Marshall SM, El Nahas M, Remuzzi G, Piras G, De Cosmo S and Viberti G: Podocyte number in normotensive type 1 diabetic patients with albuminuria. Diabetes 51: 3083-3089, 2002.

22. DallaVestra M, Masiero A, Roiter AM, Saller A, Crepaldi G and Fioretto P: Is podocyte injury relevant in diabetic nephropathy? Studies in patients with type 2 diabetes. Diabetes 52: 1031-1035, 2003.

23. Mekinová D, Chorváthová V, Volkovová K, Staruchová $M$, Grancicová E, Klvanová J and Ondreicka R: Effect of intake of exogenous vitamins $\mathrm{C}, \mathrm{E}$ and beta-carotene on the antioxidative status in kidneys of rats with streptozotocin-induced diabetes. Nahrung 39: 257-261, 1995.

24. Obrosova I, Fathallah L and Greene D: Early changes in lipid peroxidation and antioxidative defense in rat retina: Effect of DL-alpha-lipoic acid. Eur J Pharm 398: 139-146, 2000.

25. Skyrme-Jones RA, O'Brien RC, Berry KL and Meredith IT: Vitamin E supplementation improves endothelial function in type I diabetes mellitus: A randomized, placebo-controlled study. J Am Coll Cardiol 36: 94-102, 2000.

26. Gaede P, Poulsen HE, Parving HH and Pedersen O: Double-blind, randomised study of the effect of combined treatment with vitamin $\mathrm{C}$ and $\mathrm{E}$ on albuminuria in Type 2 diabetic patients. Diabet Med 18: 756-760, 2001. 
27. Liou KT, Shen YC, Chen CF, Tsao CM and Tsai SK: The anti-inflammatory effect of honokiol on neutrophils: Mechanisms in the inhibition of reactive oxygen species production. Eur J Pharmacol 475: 19-27, 2003.

28. Tuo QH, Wang C, Yan FX and Liao DF: MAPK pathway mediates the protective effects of onychin on oxidative stress-induced apoptosis in ECV304 endothelial cells. Life Sci 76: 487-497, 2004.

29. Agustian PA, Schiffer M, Gwinner W, Schäfer I, Theophile K, Modde F, Bockmeyer CL, Traeder J, Lehmann U, Grosshennig A, et al: Diminished met signaling in podocytes contributes to the development of podocytopenia in transplant glomerulopathy. Am J Pathol 178: 2007-2019, 2011.

30. Yang B, Oo TN and Rizzo V: Lipid rafts mediate $\mathrm{H} 2 \mathrm{O} 2$ prosurvival effects in cultured endothelial cells. FASEB J 20: 1501-1503, 2006.
31. Kim JH, Choi W, Lee JH, Jeon SJ, Choi YH, Kim BW, Chang HI and Nam SW: Astaxanthin inhibits $\mathrm{H} 2 \mathrm{O} 2$-mediated apoptotic cell death in mouse neural progenitor cells via modulation of P38 and MEK signaling pathways. J Microbiol Biotechnol 19: 1355-1363, 2009.

32. Kim JW, Lee JE, Kim MJ, Cho EG, Cho SG and Choi EJ: Glycogen synthase kinase 3 beta is a natural activator of mitogen-activated protein kinase/extracellular signal-regulated kinase kinase kinase 1 (MEKK1). J Biol Chem 278: 13995-14001, 2003.

33. Pap $\mathrm{M}$ and Cooper GM: Role of glycogen synthase kinase-3 in the phosphatidylinositol 3-Kinase/Akt cell survival pathway. J Biol Chem 273: 19929-19932, 1998.

This work is licensed under a Creative Commons Attribution-NonCommercial-NoDerivatives 4.0 International (CC BY-NC-ND 4.0) License. 